Коммуникация». Вып. 4. Н. Новгород : Изд-во НГЛУ им. Н.А. Добролюбова, 2003. С. 132-144.

6. Сдобников В.В., Петрова О.В. Теория перевода: Учеб. для ин-тов и фак. иностр. яз. - Москва : АСТ: Восток-Запад, 2006. С. 199-227.

7. Сдобников В.В. Проблема оценки качества перевода: коммуникативнофункциональный подход. Вестник Нижегородского государственного лингвистического университета. Серия «Лингвистика и межкультурная коммуникация». Вып. 1. Н. Новгород : Изд-во НГЛУ им. Н.А. Добролюбова, 2007. С. 74-81.

8. Шлепнёв Д.Н. К вопросу о типологии ошибок в переводе: целесообразность разграничения переводческих и лингвистических ошибок с точки зрения дидактики и практики перевода. Проблемь теории, практики и дидактики перевода: материалы II международной научной конференции. (Н. Новгород 13-15 апреля 2009 г.) Серия «Лингвистика и межкультурная коммуникация». Вып. 11. Н. Новгород : Изд-во ГОУ НГЛУ им. Н.А. Добролюбова, 2009. С. 46-48.

9. Lederer M. La traduction aujourd 'hui - le modéle interprétatif. - Paris : Hachette, 1994. P. 133-138.

10.http://www.fgosvo.ru/uploadfiles/mo/20111123094149.pdf (accessed on: 25.06.2020). P. 10.

УДК $811.511 .141 ' 28$

DOI: $10.24144 / 2617-3921.2020 .18 .291-300$

Катерина Дудич Лакатош кандидат філологічних наук, дочент кафедри філологї, Закарпатський угорський інститут імені Ференца Ракоиі II orcid.org/0000-0003-1354-4421 Україна, +380999663935 dudicslakatos@gmail.com

\title{
Належне ставлення до говірок - запорука ефективного викладання рідної мови
}

Анотаиія. $У$ подальшій частині роботи хочемо оприлюднити результати анкетування, проведених протягом останніх 10 років, які торкнулися питання щодо ставлення до угорської мови на різних рівнях закарпатської угорськомовної освіти. Дані дають відомості про те, 
наскільки реалізувалася на практиці сформульована у навчальній програмі мета та запропонований метод вивчення рідної мови. Опитування, проведені серед учнів та педагогів, засвідчили, щзо навчальні програми, які відображають нові підходи до викладання рідної мови, а також ознайомчі наукові лекції для педагогів на курсах підвищення кваліфікаџї дають свій результат: обидві групи відмежовуються від відкрито негативних суджень стосовно різних мовних варіантів та їх носїв. У ході даного дослідження підтвердилося також те, щзо засвідчили вже попередні дослідження: особа педагога, його особиста думка стосовно мовних та мовленнєвих явищ, формують мовну свідомість його учнів. Також з'ясувалося, щуо на ставлення школярів впливають не тільки позитивна чи негативна критика або зауваження педагогів. У цзьому віці на їх мовлення (так само, як на поведінку, стиль одягу, смаки) значною мірою впливає $i$ формує оточення, друзі або думка, яка пропагується різними друкованими та електронними ЗМІ. Цифри, написані та розказані історії, а також наш власний досвід та спостереження дають підстави стверджувати, щзо закарпатські угорські педагоги формують мовне ставлення учнів у належному напрямку, однак навіть вони самі не можуть повністю позбутися сформованих і закостенілих за довгі роки звичок, які відбивають стереотипи. На їх поведінку впливають очікування з боку оточення, згідно з якими вчитель повинен говорити «попанськи». Це підтверджується тим, щзо попри позитивне або принаймні толерантне ставлення стосовно діалектних явищ у мовленні інших осіб, самі педагоги-респонденти відмежовуються від них. Але бажаної мети, формування відповідного рівня комунікативної компетенції ми можемо досягти тільки тоді, коли ичі перешкоджаючі фактори будуть усунуті або принаймні зменшені. Можемо стверджувати, щзо напрям обраний правильно i педагоги намагаються його втілювати.

Ключові слова: мовне ставлення, діалект, закарпатські школярі, стереотипи

Abstract. The study presents the results of several social linguistics surveys in Transcarpathia hat were dealing with the matter of language identity in one way or the other in the past 10 years. Based on these it can be proven that the attitude towards language dialects is closely connected to successful native language education: without a real language attitude education cannot be successful; however, an objective attitude can also only be established with appropriate, responsible, scientifically founded native language education. Surveys conducted among students and their teachers prove that the teaching schedule conveying the new mother language teaching attitude, the information-centered scientific lectures given during teachers' further education courses already produced results: both groups distance themselves from openly negative opinions concerning different language variants and their users. The present research also proves what is already supported by surveys formerly quoted: the role of the teacher, their personal opinion 
concerning languages, phenomena of language use shape the language identity of their students. It also became clear that it is not only their teachers' positive or negative critics, remarks that affect the students' attitude. In this age their language use (as well as their behavior, dress code or tastes) is shaped, affected largely by the opinion of their environment, friends, or the different written or electronic media. Based on the numbers and the written and told stories and my personal experience and observations Transcarpathian Hungarian teachers direct their students' language attitude in the right direction, but even they themselves cannot get rid of their habits that were created and fixed by long years, that reflect the effect of stereotypes. They can be influenced by the expectation of the environment, according to which a teacher must speak "in a gentlemanly way". This statement is supported by the fact that although their answers concerning the dialect use of others show a positive or at least allowing attitude, they distance themselves from these language variants. The desired goal, creating an appropriate level of communication competence, however, can only be reached if these obstacles disappear, or at least weaken. It can be stated that the present direction is appropriate, and that the teachers try to follow it.

Keywords: language attitude, native language education, dialects, sociolinguistics

Вступ. Численні анкетування, дослідження доводять, що більшість мешканців, які проживають на угорськомовній території, в першу чергу засвоюють якусь говірку. Ця риса особливо характерна людям, які контактують 3 нацменшинами. Обмежене використання рідної мови (угорської) призводить до того, що угорці закордоння більш скуто вживають свою рідну мову [5, с. 60, 12, с. 233-248]. Окрім так званого мовного консерватизму, великий вплив на мовлення нацменшини має державна мова: вона стала невід'ємною частиною щоденної комунікації, більше того, зайняла чільне місце у більш формальних комунікативних ситуаціях $[6$, с.74-82, 11]. Саме у школі (чи навіть ще у дитсадку) молодь вперше стикається 3 тим, що їхню мовленнєву здатність осуджують та висміюють. Це враження може накласти відбиток на все життя. Проте важливим $\epsilon$ те, що цей осуд, а разом 3 ним й враження, носив позитивний чи негативний характер. Саме те, наскільки ми обізнані у питаннях щодо мови та її варіантів, формує відповідне ставлення до неї.

Методологія та методи дослідження. Питання ефективного та результативного викладання рідної мови споконвіків розцінювалось як надзвичайно важлива освітня та соціальна проблема [1, с. 293-297, 2, с. 407428]. Ця проблема особливо актуальна для спільнот національних меншин. Поява у 2005 році навчальної програми з угорської мови стала справжнім проривом для закарпатської угорськомовної освіти. У вступі зазначено: « $A z$ anyanyelv oktatásának fó célja annak elérése, hogy a tanuló birtokolja az anyanyelv eszközeit, annak változatait, stílusait és müfajait, szabadon és a kommunikációs 
célnak megfelelöen tudja alkalmazni ezeket a beszédtevékenység minden szférájában, azaz elérje a kommunikativ kompetencia megfelelö szintjét» («Головною метою вивчення рідної мови є засвоєння учнями засобів угорської мови, їі варіантів, стилів, а також вміння вільно використовувати ії у всіх сферах комунікативної діяльності, тобто досягнути відповідного рівня комунікативної компетенції» - переклад наш) [8, с. 3]. Для досягнення сформульованої вище мети автори пропонують побудувати урок із застосуванням зіставного методу [4, с. 44-62]. Принцип цього методу полягає в тому, щоб учні вивчали варіанти угорської у порівнянні з літературною мовою. Дотримуючись цього методу, були розроблені підручники, допоміжні матеріали, збірники вправ. До того ж, його ефективно застосовують і на курсах підвищення кваліфікації педагогів [3].

Завдяки застосування зіставного методу вже 11 років у школах Закарпаття 3 угорською мовою навчання вивчення рідної мови більш ефективне та результативне. Натомість усвідомлюємо, що між теорією і практикою простежується помітна різниця: дуже важко позбутися упередженої думки стосовно нестандартного варіанта угорської мови та іiі мовця, яка протягом багатьох років зафіксувалася у наші підсвідомості. Для результативного використання зіставного методу потрібно побудувати урок на першочерговому мовному варіанті. А для цього необхідно нейтрально відноситися до мови в цілому та позбутися зневажливого та дистанційованого ставлення до неї. Адже обов'язкою умовою ситуативної двомовності $\epsilon$ збалансоване, функціонально-ізольоване ставлення до мови [7, с. 315-317].

Виклад основного матеріалу дослідження. У подальшій частині роботи хочемо оприлюднити результати анкетування, проведених протягом останніх 10 років, які торкнулися питання щодо ставлення до угорської мови на різних рівнях закарпатської угорськомовної освіти. Дані дають відомості про те, наскільки реалізувалася на практиці сформульована у навчальній програмі мета та запропонований метод вивчення рідної мови.

У 2006-2008 роках ми опитали 1490 респондентів віком від 15 до 17 років про їхне ставлення до діалектів [10]. Дані свідчать про те, що опитані не володіють достатніми знаннями про діалекти, відхрещуються від цього варіанта мови. Майже половина 3 них стверджувала, що у регіоні, де вони проживають, не використовують говіркове мовлення, а ще більша кількість запевняє, що не володіє іншим варіантом угорської мови. 


\section{Діаграма 1. Відповіді респондентів на запитання: «Чи використовують говіркове мовлення у твоєму населеному пункті?» та «Чи розмовлясш ти говіркою?» у процентному співвідношенні, 2006-2008.}

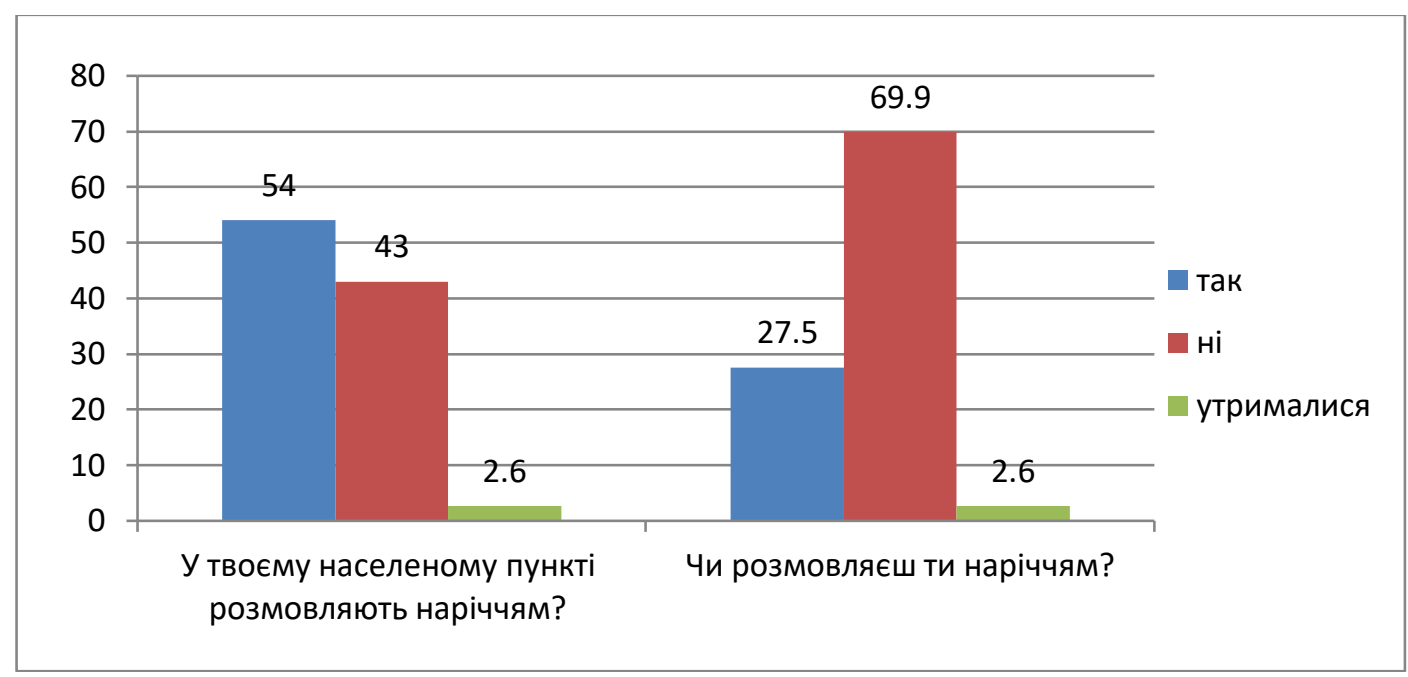

Отримані результати є не настільки разючими, як це здавалося на перший погляд. Таке відчужене ставлення до діалектів 3'явилося ще у 50-х роках минулого століття. До прикладу, з цього приводу дослідник Йожеф Вейг [13, с. 37] у 1959 році писав: «Ha egy más nyelvi közösségbe tartozó egyén a szokásostól eltérö nyelvi alakot mond, más hangszínárnyalatban és más idötartammal ejti ki a hangokat, mint ahogy a hallgató és környezete szokta, a hallgatónak feltünik a különbség» («Якщо особа, яка відноситься до іншого мовного середовища, у свойй мові вживає інші, нехарактерні мовні форми, зі своєрідною інтонацією та іншою тривалістю вимовляє ті чи інші звуки, то слухач помітить різниию» - переклад наш). У мовленні інших люди помічають не «традиційні» мовні явища та присовують їх мовцю.

Окрім учнів шкіл різного типу, анкету заповнили й 25 випускників Мукачівського педагогічного училища. Сюди може вступити молодь, яка здобула неповну середню освіту, i, провчившись чотири роки, отримає диплом молодшого спеціаліста. Чимала кількість випускників педінституту одразу ж працевлаштовуються, продовжуючи заочно навчатися у вищому навчальному закладі.

Від цієї групи респондентів по праву могли очікувати більш усвідомлені та професійні відповіді. Адже вони приймають у свої класи шестирічних дітей, більшість яких розмовляє говіркою. Проте результати опитування вказують на інше (див. діаграму 2) 


\section{Діаграма 2. Відповіді випускників Мукачівського педучилища на запитання: «Чи використовують говіркове мовлення у твосму населеному пункті?» та «Чи розмовляєш ти говіркою?» у процентному спів відношенні, 2006-2008.}

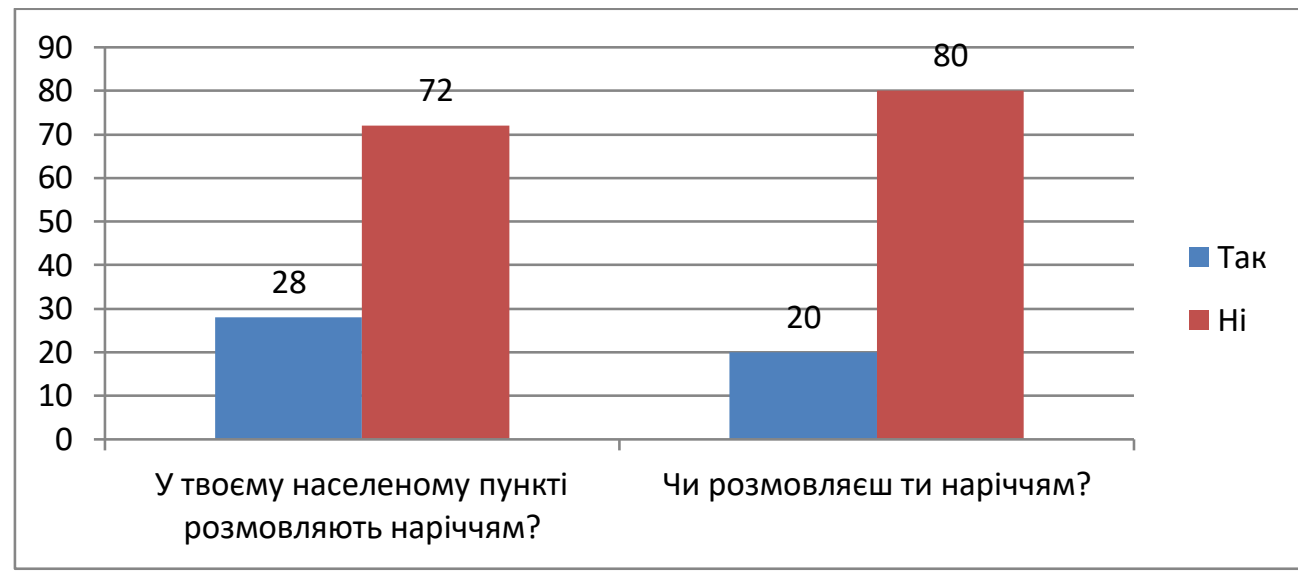

$12 \%$ опитаних випускників вважають правильним, а $60 \%$ - задовільним, якщо хтось розмовляє говіркою постійно, пояснюючи це тим, що«о̋ $k$ igy tanulták meg anyanyelvüket, és nekik ez helyes, nem tehet róla», «így nem halnak ki a tájszólások» («вони саме так вивчали рідну мову і їм це так правильно, він не винний у иььому», «в такий спосіб говірки існуватимуть $і$ надалі»). 28\% майбутніх вчителів не вважає правильним постійно спілкуватися наріччям, аргументуючи це тим, що «а magyar nyelvet a magyar nyelvnek illöen kell beszélni», «nem helyesen beszél magyar nyelven», «nem szép», «szerintem csúnya, ügyelniük kellene», "tudni kell a helyes és értelmes kifejezésmódot, szavakat» («угорською потрібно розмовляти так, як належно», "він неправильно говорить угорською», «це негарно», «ие неетично, хай слідкує за свойм мовленням», «потрібно знати правильно та чітко висловлюватися».

У той же час $64 \%$ респондентів не хочуть, щоб загальнонародна мова повністю зникла. Більшість із них вважає говори частиною угорської культури, яскравою родзинкою угорської мови та зрешта доброю традицією.

Паралельно ми попросили 150 угорських педагогів заповнити анкету стосовно їхнього ставлення до діалектів [9, с. 423-430]. Більшість опитаних закарпатських педагогів знаходяться на певному рівні двомовності 3 домінуванням угорської. Вони зізнаються, що переважно користуються угорською розмовною мовою як на робочому місці, так і поза ним. Опитування засвідчило, що вони відчувають різницю між закарпатським і угорським мовними варіантами: в першу чергу відмінність вбачають у явищі міжмовних контактів та більшому використанні діалектних явищу мовленні. Попри це вони рішуче вважають гарнішим мовлення саме своєї території. Більшість сформулювала поняття діалекту: вважають йогоу першу чергу вираженням традиції, ідентичності. Хоча вони визнають, що використовують діалект усвоєму середовищі, виражаючицим певну дистанціювальну аттітюду. Причиною цього є ймовірноупереджена думка стосовно діалектів та їх носіїв. 
Хоча респонденти відкрито відмежовуються від негативних стереотипів стосовно носіїв діалектів, однак не можуть повністю уникнути їхніх впливів. На це вказують особисті формулювання T/3 про носіїв діалектів: себе вони до них не зараховують. Вселяє надію те, що попри тримання дистанції цей варіант має в їхньому середовищі прихований престиж: вони вважають важливим його збереження та шкодуватимуть у разі його втрати.

Приємно, що (як свідчать відповіді респондентів) у сфері середньої освіти використовуються результати найновіших лінгвістичних досліджень. Попри зменшену кількість годин педагоги вважають своїм завданням ознайомлювати з ними учнів. Також респонденти вважають важливою роль педагога в збереженні угорськомовної системи освіти на Закарпатті, у просвітній діяльності в середовищі молоді та батьків. У більшості випадків статистично спостерігається значна різниця між відповідями сільських та міських педагогів та між відповідями педагогів, що викладають рідну мову, i тими, хто викладає не рідну мову.

$75,8 \%$ опитаних зізналися в тому, що у своїй педагогічній діяльності вже виправляли учнів через уживання ними говіркових елементів. Пояснення зовсім невтішні. Ось кілька з них: «Azért, hogy a helyes ejtést és irást tanitsam meg», «Azért, mert magyar nyelven másképp kell mondani. Egyszerüen helytelennek tartom», «magyar nyelven így helyes» («виправляв(ла) тому, щзоб навчити правильному написанню та вимові», «виправляв(ла) тому, бо угорською це поіншому кажуть. Просто вважаю їхнс мовлення неправильним», «угорською правильно так»). Коли дитина чує від вчительки такі аргументи, то може повірити, що він та його батьки неналежно володіють угорською мовою.

Натомість деякі вчителі належну професійну підготовку. Вони пояснюють дітям вживання того чи іншого мовного елементу наступним чином: «így is lehet, de a köznyelvben így használjuk» («так теж кажуть, але літературною мовою вживається саме так»).

У колі вчителів угорської мови теж дотримуються вищезгаданої аргументації: АA nyilvános beszédben igyekezzen a köznyelvi formát használni, egyébként nem hibás, szégyellnivaló dolog», «A nyelvjárás fontos kincsünk, nem elítélendö, nem szégyen, de kell ismernünk a helyes köznyelvet. Odahaza nyugodtan beszélhet nyelvjárásban, a közéletben tudni kell így megnyilatkozni», «az órán tapintatosan, próbálkozom a köznyelv használatára, de sajnos mostanság egyre ritkábban kell «javitanom» («У щзоденному спілкуванні намагаюся послуговуватися загальнонародною мовою, до того ж, вона не є неправильною чи чимось таким, чого потрібно соромитися», "Діалекти - ие наш скарб, їх не потрібно соромитися, проте нам необхідно знати й унормовану форму загальнонародної мови. Вдома хай спокійно розмовляе говіркою, а в суспільному житті потрібно знати висловитися й літературною мовою», «на уроиі намагаюся тактовно вживати загальнонародну мову, проте тепер доводиться «виправляти» учнів» рідше). 
Натомість зі школярами працюють не лише вчителі рідної мови, більше того інші педагоги теж мають власну точку зору щодо вживання мови i діляться 3 нею зі своїми вихованцями. Навіть тим вчителям важко використовувати на практиці новий метод навчання, які регулярно беруть участь у різних конференціях, присвячених цьому питанню, відвідують курси підвищення кваліфікації або ж читають відповідні інструктивно-методичні матеріали.

$\mathrm{Ti}$, хто лише в школі вивчали рідну мову і вищу освіту здобували не угорською мовою (а це у більшості випадків), висловили такі думки стосовно вживання говорів у шкільній практиці: «...ezáltal a helyes magyar beszéd elfajult lesz, nem lesz „tiszta”», «nem szép, nem kulturált», «sérti a fülemet», «rögtön látni azon, honnan jött», «úgy tartom helyesnek, ha az iskolában szépen, magyarul beszélünk», «beszéljünk csak szépen, tisztán magyarul» («ųe nсyє правильне угорське мовлення, воно стане «нечистим», "це негарно, некультурно», "ріже вухо», «одразу видно, звідки прийшов», «вважаю правильним, якщо в школах розмовляють літературною угорською мовою»).

Як бачимо, у цих аргументах, висловлюваннях дуже часто зустрічаємо вислови «правильний», «чиста угорська мова». Це є залишком старого методу навчання, що протягом довгих років було запрограмовано в нашій свідомості. Більшість педагогів вважає, що їхнім першочерговим завданням є збереження правильності та чистоти мовлення. Наступна цитата $є$ підтвердженням цього: «helyesen beszéljen, kötelességemnek tartom» («мій обов'язок навчити учня розмовляти правильно»).

Висновки. Було б доцільно, якщо дитина, яка розмовляє говіркою, вже 3 першого класу не цуралася вживати у своєму мовленні діалектні мовні конструкції. Проте для цього потрібно було б внести зміни до навчальної програми для початкових класів, а також змінити метод викладання. Адже, як це вказано у назві нашої статті, ставлення до діалектів тісно пов'язане 3 ефективним вивченням рідної мови: без усвідомленого ставлення до мови в цілому, не буде результативним навчання, а об’єктивне ставлення може сформуватися лише в комплексі 3 відповідним, науково обгрунтованим викладанням рідної мови. Про це свідчать відповіді 55 випускників 6 різних шкіл (див. діаграму 3). 


\section{Діаграма 3.Відповіді респондентів на запитання: «Чи використовують говіркове мовлення у твосму населеному пункті?» та «Чи розмовляєш ти говіркою?» у відсотковому співвідношенні, 2016.}

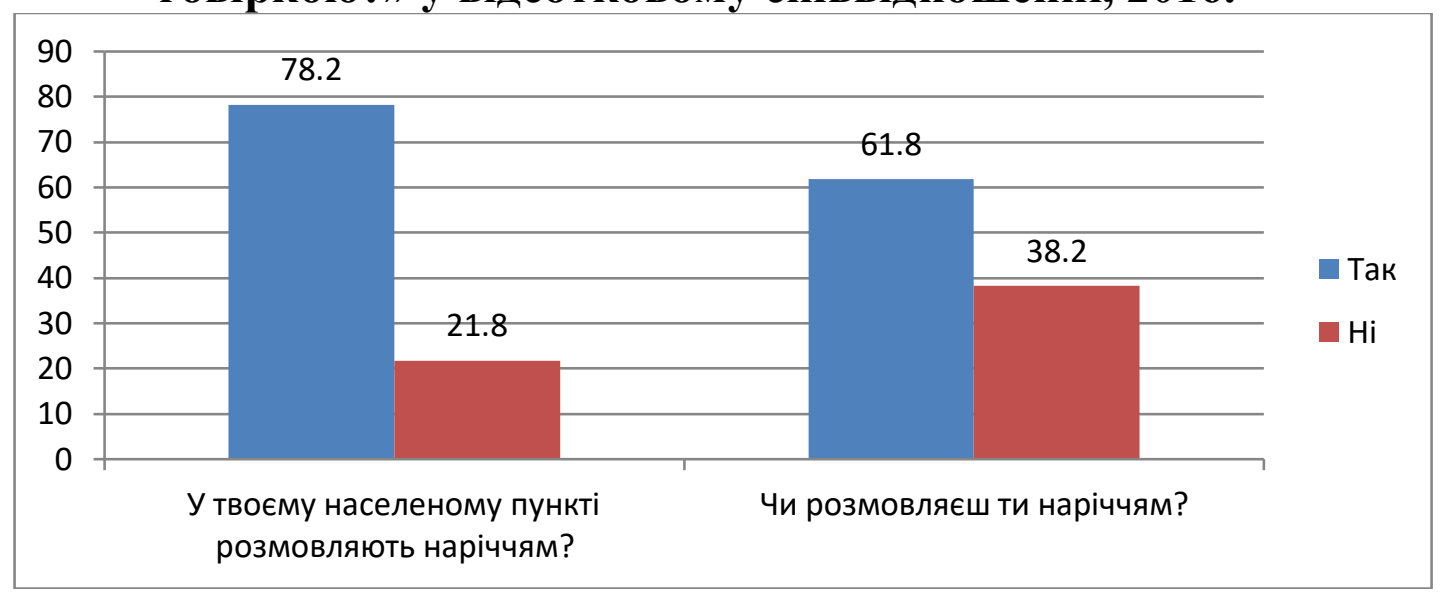

Порівнюючи дані діаграм 1 та 3, з упевненістю можемо стверджувати: опитані учні усвідомлено висловлюють свою позицію стосовно варіантності рідної мови. Опитування, проведені серед учнів та педагогів, засвідчили, що навчальні програми, які відображають нові підходи до викладання рідної мови, а також ознайомчі наукові лекції для педагогів на курсах підвищення кваліфікації дають свій результат: обидві групи відмежовуються від відкрито негативних суджень стосовно різних мовних варіантів та їх носіїв. У ході даного дослідження підтвердилося (при порівнянні відповідей обох груп) також те, що засвідчили вже попередні дослідження: особа педагога, його особиста думка стосовно мовних та мовленнєвих явищ формують мовну свідомість його учнів. Також 3'ясувалося, що на аттітюду школярів впливають не тільки позитивна чи негативна критика або зауваження педагогів. У цьому віці на їх мовлення (так само, як на поведінку, стиль одягу, смаки) значною мірою впливає і формує оточення, друзі або думка, яка пропагується різними друкованими та електронними 3МІ.

Припускаємо, що це результат використання зіставного методу на уроках рідної мови. Для того, щоб упевнитися в цьому, потрібно провести більш точні дослідження.

\section{ЛIТЕРАТУРА}

1. Antalné Szabó Á. A szociolingvisztika mint szemlélet, mint tudás, mint pedagógia az iskolában. / Hajdú M., Keszler B. szerk. Köszöntő könyv Kiss Jenö 60. születésnapjára. Budapest: ELTE Magyar Nyelvtudományi és Finnugor Intézete és a Magyar Nyelvtudományi Társaság, 2003. 293-297.

2. Antalné Szabó Á. Az anyanyelvi nevelés új stratégiái. Magyar Nyelvőr 127: 2004. 407-428. 
3. Beregszászi A. A lehetetlent lehetni. Tantárgy-pedagógiai útmutató és feladatgyüjtemény az anyanyelv oktatásához a kárpátaljai magyar iskolák 59. osztályában. Budapest: Tinta Könyvkiadó, 2012. 111 o.

4. Beregszászi A., Csernicskó I. A kárpátaljai magyar nyelvjárások és az iskola: elméleti és módszertani kérdések. Acta Beregsasiensis, VI. évfolyam, 1. kötet: 2007. 44-62.

5. Csernicskó I. szerk. A mi szavunk járása. Ungvár: PoliPrint, 2003. 2920.

6. Karmacsi Z. A tiszaújlaki lakosok nyelvválasztási szokásai. / Csernicskó I. szerk. A mi szavunk járása. Ungvár: PoliPrint, 2003.74-82.

7. Kiss J. A nyelvjárásokhoz és a köznyelvhez való viszonyulás: attitüdváltozások a magyar nyelvközösségben. / Zoltán A. szerk. Nyelv, stílus, irodalom. Köszöntö könyv Péter Mihály 70. születésnapjára. Budapest: ELTE BTK Keleti szláv és Balti Filológiai Tanszéke, 1998. 315317.

8. Kótyuk I., mtsai. Magyar nyelv 5-12. osztály. Tanterv a magyar tannyelvü iskolák számára. Csernyivci: Bukrek, 2005. 160 o.

9. Lakatos K. Kárpátaljai pedagógusok és a nyelvjárások (Egy fölmérés tanulságaiból). / Borbély A., Vančoné Kremmer I., Hattyár H. szerk. Nyelvideológiák, attitüdök és sztereotípiák. Budapest-DunaszerdahelyNyitra: MTA Nyelvtudományi Intézet-Gramma Nyelvi Iroda-Konstantin Filozófus Egyetem Közép-európai Tanulmányok Kar, 2009. 423-430.

10. Lakatos K. Kárpátaljai magyar iskolások nyelvi tudata és attitüdje. PhDértekezés. Budapest: ELTE Nyelvtudományi Doktori Iskola, 2010. 222 o.

11. Márku A. „Po zákárpátszki" Kétnyelvűség, kétnyelvüségi hatások és kétnyelvü kommunikációs stratégiák a kárpátaljai magyar közösségben. Ungvár: „Líra” Poligráf centrum, 2013. 244 o.

12. P. Lakatos I., T. Károlyi M. Nyelvi változások az északkeleti régióban a trianoni határ két oldalán. / Hoffmann I., Juhász D., Péntek J. szerk. Hungarológia és dimenzionális nyelvszemlélet. Debrecen-Jyväskylä, 2002. 233-248.

13. Végh J. Örségi és hetési nyelvatlasz. Budapest: Akadémiai Kiadó, 1959. 214 o. 